\title{
Upregulation of $\beta 2$-microglobulin expression in progressive human oral squamous cell carcinoma
}

\author{
QIAN JIANG $^{1 *}$, SDEK PATIMA $^{2^{*}}$, DONG-XIA YE ${ }^{1}$, HONG-YA PAN $^{1}$, \\ PIN ZHANG ${ }^{1}$ and ZHI-YUAN ZHANG ${ }^{1}$ \\ ${ }^{1}$ Department of Oral and Maxillofacial Surgery, Ninth People's Hospital, Shanghai Research Institute of Stomatology, \\ Shanghai Key Laboratory of Stomatology, Shanghai, P.R. China; ${ }^{2}$ Division of Cardiology, \\ University of California at Los Angeles, The Cardiovascular Research Laboratory, \\ Department of Medicine, David Geffen School of Medicine, Los Angeles, CA, USA
}

Received July 12, 2011; Accepted November 4, 2011

DOI: 10.3892/or.2011.1613

\begin{abstract}
The aim of the present study was to investigate $\beta 2$-microglobulin $(\beta 2-\mathrm{M})$ expression in normal oral mucosa and progressive oral squamous cell carcinoma (OSCC) and to assess the clinical significance of $\beta 2$-microglobulin expression. The study included 10 cases of normal oral mucosa epithelium specimens, 55 cases of primary OSCC specimens, and 25 cases of OSCC metastasis specimens. Immunohistochemistry was used to determine $\beta 2-\mathrm{M}$ expression, and its correlation with clinicopathological factors in progressive OSCC was evaluated. Immunohistochemistry showed that strong $\beta 2-\mathrm{M}$ expression was significantly asscociated with tumor size (T3, $\mathrm{T} 4$ vs. T1, T2; $\mathrm{P}=0.001$ ), positive node status ( $\mathrm{N}$ positive vs. $\mathrm{N}$ negative; $\mathrm{P}=0.000)$ and advanced clinical stage (III, IV vs. I, II, $\mathrm{P}=0.000$ ) in primary OSCC lesions. Compared to primary OSCC lesions, the frequency of $\beta 2-\mathrm{M}$ expression was significantly increased in metastatic OSCC lesions $(\mathrm{P}=0.02)$. In addition, in vitro results from Western blotting showed increased $\beta 2-\mathrm{M}$ expression in the two OSCC lines studied. Therefore, we speculate that the up-regulation of $\beta 2-\mathrm{M}$ expression may contribute to the oncogenesis of human oral mucosa, tumor invasion and metastasis.
\end{abstract}

Correspondence to: Dr Zhi-Yuan Zhang, Department of Oral and Maxillofacial Surgery, Ninth People's Hospital, Shanghai Research Institute of Stomatology, Shanghai Key Laboratory of Stomatology, Shanghai, P.R. China

E-mail: zhangzhiyuan502@126.com

*Contributed equally

Abbreviations: OSCC, oral squamous cell carcinoma; MHC, major histocompatibility complex; HLAs, human leukocyte antigens; NK, natural killer; HIOECs, human immortalized oral epithelial cells

Key words: oral squamous cell carcinoma, $\beta 2$-microglobulin, invasion, metastasis, immunohistochemical staining

\section{Introduction}

Oral squamous cell carcinoma (OSCC) is the sixth most common cancer in the world (1). Postoperative quality of life for patients with OSCC has improved in recent years (2). However, the 5-year survival rate has not improved significantly. Furthermore, $30-40 \%$ of patients without evidence of nodal disease at resection eventually die from metastatic spread (3). The identification of biomarkers for evaluating the progression of OSCC is therefore urgent.

It has been suggested that $\beta 2$-microglobulin $(\beta 2-\mathrm{M})$ expression in tissues may be involved in OSCC progression and metastasis (4). $\beta 2-\mathrm{M}$ is a non-glycosylated protein with a molecular mass of 11,800 Da and is synthesized by all nucleated cells (5). It is present on the surface of all nucleated cells except for red blood cells (6). $\beta 2-\mathrm{M}$ forms the $\beta$ chain of the major histocompatibility complex (MHC) class I molecule [also known as human leukocyte antigens (HLAs) in humans] and has a 7-stranded $\beta$-pleated structure, which is believed to function in antigen presentation to cytotoxic $\left(\mathrm{CD}^{+}\right) \mathrm{T}$ lymphocytes (7). Upon recognition of foreign peptide antigens on cell surfaces, $T$ cells actively bind and lyse antigen-presenting cancer cells. In $\beta 2-\mathrm{M}$-deficient mice, antibody $(\mathrm{Ab})$ responses are defective, and natural killer (NK) cells with increased sensitivity attack cells lacking the MHC class I molecule $(8,9)$. In addition to the roles in immunity, the level of $\beta 2-\mathrm{M}$ is associated with proliferation, apoptosis and metastasis in several cancer types $(10,11)$, and is a predictor of survival in patients with certain types of cancer (12). $\beta 2-\mathrm{M}$ was found to promote the growth of human renal cell carcinoma through the activation of the protein kinase A, cyclic AMP-responsive element-binding protein, and vascular endothelial growth factor axis (11). Overexpression of $\beta 2-\mathrm{M}$ in human prostate cancer cell lines leads to inhibition of tumor growth in vivo and using the $\beta 2-\mathrm{M} \mathrm{Ab}$ to interrupt $\beta 2-\mathrm{M}$ signaling in human prostate cancer cell lines inhibits cancer cell growth and induces cell apoptosis (13).

The aim of this study was to investigate $\beta 2-\mathrm{M}$ expression in normal oral mucosa and progressive OSCC and to assess the clinical significance of $\beta 2-\mathrm{M}$ expression. The results of our 
study may contribute to a better understanding of the clinical significance of alterations in $\beta 2-\mathrm{M}$ expression and may lead to further insights into the mechanisms to control progression and metastatic spread of tumor cells in OSCC patients.

\section{Materials and methods}

Cell cultures. Normal human oral keratinocytes (NHOKs) and human immortalized oral epithelial cells (HIOECs) $(14,15)$ were cultured in defined keratinocyte medium-SFM (cat. no. 10744; Gibco, USA). CAL27 was purchased from ATCC (Manassas, VA). The OSC-4 cells were from Kochi Medical School, Japan. The CAL27 cells were cultured in DMEM (Invitrogen) with supplements (10\% fetal bovine serum, $1 \%$ glutamine and $1 \%$ penicillin-streptomycin). The OSC-4 cells were cultured in RPMI-1640 (Invitrogen) with the same supplements.

Western blotting. Protein extracts were prepared from $1 \times 10^{6}$ cells using standard procedures. Cell lysates containing $20 \mu \mathrm{g}$ protein were subjected to Western blot analysis. The primary $\mathrm{Ab}$ was monoclonal mouse anti- $\beta 2-\mathrm{M}$ (sc-13565, 1:1000; Santa Cruz Biotechnology Inc.), and tubulin was detected as input control using monoclonal mouse antitubulin (T9026, 1:50,000; Sigma), Blots were developed with Immobilon Western Chemiluminescent HRP Substrate (Millipore, USA).

Tissue specimens. Tissue specimens were obtained from the files of the Department of Oral and Maxillofacial Surgery, Shanghai Ninth People's Hospital, Shanghai Jiao Tong University School of Medicine, China. All tissue samples had been fixed in $10 \%$ buffered formalin and embedded in paraffin wax. For primary OSCC lesions obtained from 50 untreated patients, who underwent surgery between 2008 and 2009 , clinicopathological data, including gender, age, tumor site, primary tumor stage $(\mathrm{T})$, lymph node status $(\mathrm{N})$ and tumornode-metastasis (M) were obtained from the patient clinical records and pathological reports (Table I). Clinical stage was determined according to the 2002 American Joint Committee on Cancer (AJCC) staging system. Histopathological diagnosis and grading were confirmed using haematoxylin and eosin-stained sections according to the criteria mentioned in 'Histological Typing of Tumors of the Upper Respiratory Tract and Ear', WHO, 2nd edition. All data were re-examined independently by two of the authors. Metastatic OSCC lesions from 25 patients were obtained prior to biotherapy or chemotherapy between 2008 and 2009, and data including gender, age, and metastatic type was collected. (Table II). Analyses of the tissue samples are documented in Tables III-V. Histologically normal oral mucosa samples were obtained from 10 patients who underwent dental extractions. The human studies were approved by the institutional ethics committee.

Immunohistochemical staining. Formalin-fixed, paraffinembedded tissue sections were dewaxed with xylene and rehydrated by passage through decreasing concentrations of ethanol (100-80\%). Endogenous peroxidase activity was blocked by a 20 -min incubation at room temperature with $3 \%$ $\mathrm{H}_{2} \mathrm{O}$. The sections were heated using a water bath at $100^{\circ} \mathrm{C}$

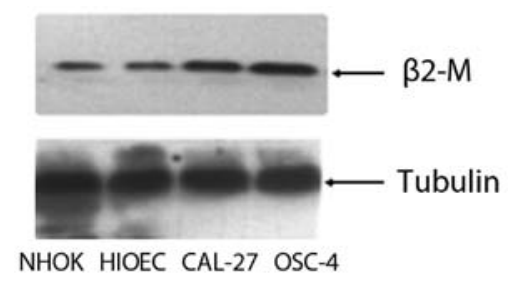

Figure 1. $\beta 2-\mathrm{M}$ protein is up-regulated in oral squamous cell carcinoma Western blot analysis of $\beta 2-\mathrm{M}$ protein expression in NHOKs, HIOECs CAL-27 cells and OSC- 4 cells. The $\beta 2-\mathrm{M}$ protein expression in CAL-27 and OSC-4 cells was higher than that in the NHOKs and HIOECs. Data are representative of 3 independent experiments.

with $0.01 \mathrm{M}$ citrate buffer solution ( $\mathrm{pH}, 6.0$ ) for $20 \mathrm{~min}$, and incubated with an optimal amount of affinity-purified monoclonal mouse anti-human $\beta 2-\mathrm{M}$ (sc-13565, 1:50; Santa Cruz Biotechnology) overnight at $4^{\circ} \mathrm{C}$. Sections were stained with liquid DAB substrate-chromogen, and counterstained with hematoxylin. Negative controls were carried out by omitting the primary Ab. The percentage of stained tumor cells in each lesion was enumerated independently by two investigators who had no knowledge of the patient characteristics. Variations in the percentage of stained cells as counted were within a $10 \%$ range. We scored the staining results according the report of Kageshita et al (16). Briefly, OSCC lesions consisting of $>75 \%$ immunostained OSCC cells within the entire lesion were scored as homogeneously positive, those having $25-75 \%$ immunostained OSCC cells were heterogeneously positive, and those with $<25 \%$ immunostained OSCC cells were negative.

Statistical analysis. Several clinicopathological factors were evaluated in the primary OSCC lesions, including gender, age ( $\leq 61$ years vs. $>61$ years), $\mathrm{T}$ stage (T1, T2 vs. T3, T4), $\mathrm{N}$ status (negative vs. positive) and clinical stage (stage I, II vs. stage III, IV). Pearson Chi-square test, Continuity Correction test and Fisher's exact test were used to evaluate the correlation between the clinicopathological variables and the $\beta 2-\mathrm{M}$ staining score using SPSS software v13.0 (SPSS Inc., USA). Differences in the $\beta 2-\mathrm{M}$ staining score between primary OSCC samples and metastatic OSCC samples were also analyzed using the Chi-square test. A P-value $<0.05$ was considered to denote significant difference.

\section{Results}

Expression of $\beta 2-M$ in primary cultured NHOKs and HIOECs and the OSCC cell lines. We compared the expression levels of $\beta 2-\mathrm{M}$ in NHOKs and HIOECs and in the two OSCC cancer cell lines (OSC and CAL27) by Western blotting. NHOKs were isolated and cultured as described (14). HIOECs were established by overexpression of HPV16 E6 and E7 protein (14). Western blot analysis revealed that $\beta 2-\mathrm{M}$ protein expression was increased in the OSC and CAL27 cells compared to the NHOKs and HIOECs (Fig. 1).

Expression of $\beta 2-M$ in normal oral mucosa epithelial and OSCC tissue specimens. We performed immunohistochemical staining using normal oral mucosa and OSCC tissue 
Table I. Profiles of the patients with primary oral squamous cell carcinoma.

\begin{tabular}{|c|c|c|c|c|c|c|c|c|}
\hline No & Gender & $\begin{array}{c}\text { Age } \\
\text { (years) }\end{array}$ & Location & $\begin{array}{l}\text { Pathological } \\
\text { grade }\end{array}$ & TNM & $\begin{array}{l}\text { Clinical } \\
\text { stage }\end{array}$ & $\begin{array}{l}\text { Smoking } \\
\text { Alcohol } \\
\text { consumption }\end{array}$ & $\beta 2$-microglobulin \\
\hline 1 & M & 54 & Palate & G1 & T3N1M0 & III & Yes & Homogeneous \\
\hline 2 & $\mathrm{~F}$ & 63 & Gingivae & $\mathrm{G} 2$ & T3N1M0 & III & No & Homogeneous \\
\hline 3 & M & 48 & Tongue & $\mathrm{G} 2$ & T2N1M0 & III & Yes & Homogeneous \\
\hline 4 & $\mathrm{~F}$ & 54 & Tongue & $\mathrm{G} 2$ & T2N1M0 & III & No & Homogeneous \\
\hline 5 & $\mathrm{~F}$ & 62 & $\begin{array}{l}\text { Floor of } \\
\text { the mouth }\end{array}$ & G1 & T4N1M0 & IV & Yes & Homogeneous \\
\hline 6 & M & 35 & Tongue & $\mathrm{G} 2$ & T4N1M0 & IV & No & Homogeneous \\
\hline 7 & $\mathrm{~F}$ & 71 & Tongue & G3 & T3N1M0 & III & No & Homogeneous \\
\hline 8 & M & 55 & Tongue & G2 & T4N1M0 & IV & No & Homogeneous \\
\hline 9 & $\mathrm{~F}$ & 64 & Gingivae & G1 & T3N0M0 & III & Yes & Heterogeneous \\
\hline 10 & M & 65 & Tongue & G2 & T2N0M0 & II & No & Negative \\
\hline 11 & M & 64 & Tongue & $\mathrm{G} 2$ & T3N0M0 & III & Yes & Heterogeneous \\
\hline 12 & $\mathrm{~F}$ & 54 & Tongue & G2 & T2NOM0 & II & No & Negative \\
\hline 13 & $\mathrm{~F}$ & 53 & Tongue & G1 & T1N0M0 & I & No & Negative \\
\hline 14 & $\mathrm{M}$ & 57 & Tongue & G2 & T2N1M0 & III & Yes & Heterogeneous \\
\hline 15 & $\mathrm{M}$ & 40 & Buccal & G2 & T3N1M0 & III & No & Homogeneous \\
\hline 16 & M & 51 & Tongue & G2 & T4N2M0 & IV & No & Homogeneous \\
\hline 17 & $\mathrm{M}$ & 44 & Tongue & G2 & T4N1M0 & IV & No & Homogeneous \\
\hline 18 & $\mathrm{~F}$ & 67 & Gingivae & G1 & T3N1M0 & III & Yes & Homogeneous \\
\hline 19 & $\mathrm{~F}$ & 73 & $\begin{array}{l}\text { Floor of } \\
\text { the mouth }\end{array}$ & G2 & T4N1M0 & IV & Yes & Homogeneous \\
\hline 20 & $\mathrm{M}$ & 63 & Tongue & G2 & T2N1M0 & III & No & Homogeneous \\
\hline 21 & M & 58 & Tongue & G2 & T2N1M0 & III & Yes & Homogeneous \\
\hline 22 & $\mathrm{~F}$ & 65 & Gingivae & G1 & T3N1M0 & III & Yes & Homogeneous \\
\hline 23 & M & 58 & Buccal & $\mathrm{G} 2$ & T4N1M0 & IV & No & Homogeneous \\
\hline 24 & $\mathrm{~F}$ & 53 & Palate & $\mathrm{G} 2$ & T2N1M0 & III & No & Heterogeneous \\
\hline 25 & M & 54 & $\begin{array}{l}\text { Floor of } \\
\text { the mouth }\end{array}$ & G3 & T4N0M0 & IV & No & Heterogeneous \\
\hline 26 & $\mathrm{M}$ & 59 & Tongue & G1 & T1N1M0 & III & Yes & Heterogeneous \\
\hline 27 & $\mathrm{M}$ & 60 & Tongue & G2 & T2N0M0 & II & No & Negative \\
\hline 28 & $\mathrm{~F}$ & 50 & Tongue & G1 & T4N0M0 & IV & No & Homogeneous \\
\hline 29 & M & 51 & Buccal & G1 & T2N0M0 & II & No & Heterogeneous \\
\hline 30 & M & 42 & Palate & G3 & T2N0M0 & II & Yes & Heterogeneous \\
\hline 31 & M & 65 & Tongue & G2 & T2NOM0 & II & No & Negative \\
\hline 32 & M & 76 & Tongue & G2 & T3N0M0 & III & Yes & Heterogeneous \\
\hline 33 & $\mathrm{~F}$ & 34 & Tongue & G2 & T2N0M0 & II & Yes & Negative \\
\hline 34 & $\mathrm{~F}$ & 44 & Tongue & G1 & T1N0M0 & I & Yes & Negative \\
\hline 35 & $\mathrm{~F}$ & 68 & Buccal & G2 & T2N1M0 & III & Yes & Heterogeneous \\
\hline 36 & M & 60 & Buccal & G2 & T3N1M0 & III & No & Homogeneous \\
\hline 37 & M & 68 & Tongue & G2 & T4N2M0 & IV & No & Homogeneous \\
\hline 38 & $\mathrm{M}$ & 61 & Gingivae & G2 & T4N1M0 & IV & No & Homogeneous \\
\hline 39 & $\mathrm{~F}$ & 66 & Gingivae & G2 & T3N0M0 & III & Yes & Negative \\
\hline 40 & $\mathrm{~F}$ & 65 & Buccal & $\mathrm{G} 2$ & T4N1M0 & IV & Yes & Homogeneous \\
\hline 41 & $\mathrm{M}$ & 65 & Tongue & $\mathrm{G} 2$ & T2N1M0 & III & No & Homogeneous \\
\hline 42 & $\mathrm{M}$ & 58 & Tongue & G2 & T2N0M0 & II & Yes & Homogeneous \\
\hline 43 & $\mathrm{~F}$ & 72 & Gingivae & G2 & T3N1M0 & III & Yes & Homogeneous \\
\hline 44 & $\mathrm{M}$ & 74 & Buccal & G3 & T4N1M0 & IV & Yes & Homogeneous \\
\hline 45 & $\mathrm{M}$ & 60 & Palate & G2 & T2N0M0 & II & No & Heterogeneous \\
\hline 46 & $\mathrm{~F}$ & 73 & Tongue & G3 & T4N0M0 & IV & No & Heterogeneous \\
\hline 47 & M & 49 & Tongue & G2 & T1N1M0 & III & Yes & Heterogeneous \\
\hline 48 & M & 54 & Tongue & G2 & T2NOM0 & II & Yes & Negative \\
\hline 49 & $\mathrm{~F}$ & 67 & Buccal & G3 & T4NOM0 & IV & No & Heterogeneous \\
\hline 50 & F & 52 & Tongue & G1 & T2NOM0 & II & No & Heterogeneous \\
\hline
\end{tabular}


Table II. Profiles of the patients with metastatic oral squamous cell carcinoma.

\begin{tabular}{|c|c|c|c|c|c|}
\hline No & Gender & Age (years) & Location & Type & $\beta 2$-microglobulin \\
\hline 1 & M & 58 & Tongue & Lymph node & Homogeneous \\
\hline 2 & M & 64 & Buccal & Lymph node & Heterogeneous \\
\hline 3 & $\mathrm{~F}$ & 65 & Tongue & Lymph node & Homogeneous \\
\hline 4 & $\mathrm{~F}$ & 67 & Tongue & Lymph node & Homogeneous \\
\hline 5 & $\mathrm{~F}$ & 67 & Tongue & Lymph node & Homogeneous \\
\hline 6 & M & 56 & Tongue & Lymph node & Homogeneous \\
\hline 7 & M & 54 & Tongue & Lymph node & Homogeneous \\
\hline 8 & $\mathrm{~F}$ & 60 & Tongue & Lymph node & Homogeneous \\
\hline 9 & $\mathrm{M}$ & 61 & Tongue & Lymph node & Homogeneous \\
\hline 10 & $\mathrm{~F}$ & 80 & Buccal & Lymph node & Homogeneous \\
\hline 11 & $\mathrm{~F}$ & 81 & Buccal & Lymph node & Homogeneous \\
\hline 12 & $\mathrm{~F}$ & 86 & Tongue & Lymph node & Homogeneous \\
\hline 13 & M & 88 & Tongue & Lymph node & Homogeneous \\
\hline 14 & $\mathrm{~F}$ & 49 & Buccal & Lymph node & Heterogeneous \\
\hline 15 & $\mathrm{~F}$ & 49 & Buccal & Lymph node & Homogeneous \\
\hline 16 & M & 43 & Tongue & Lymph node & Homogeneous \\
\hline 17 & $\mathrm{M}$ & 67 & Tongue & Lymph node & Homogeneous \\
\hline 18 & $\mathrm{M}$ & 78 & Tongue & Lymph node & Homogeneous \\
\hline 19 & M & 86 & Buccal & Lymph node & Homogeneous \\
\hline 20 & $\mathrm{M}$ & 38 & Tongue & Lymph node & Homogeneous \\
\hline 21 & $\mathrm{M}$ & 67 & Buccal & Lymph node & Homogeneous \\
\hline 22 & $\mathrm{M}$ & 88 & Tongue & Lymph node & Homogeneous \\
\hline 23 & $\mathrm{~F}$ & 55 & Tongue & Lymph node & Homogeneous \\
\hline 24 & $\mathrm{M}$ & 49 & Tongue & Lymph node & Homogeneous \\
\hline 25 & M & 67 & Tongue & Lymph node & Homogeneous \\
\hline
\end{tabular}

Table III. $\beta 2$-microglobulin antigen expression in normal oral mucosa epithelial and oral squamous cell carcinoma specimens.

\begin{tabular}{lcc}
\hline Staining pattern & $\begin{array}{c}\text { Normal oral } \\
\text { mucosa epithelial } \\
\text { specimens } \\
\mathrm{n}(\%)\end{array}$ & $\begin{array}{c}\text { Oral squamous } \\
\text { cell carcinoma } \\
\text { specimens } \\
\mathrm{n}(\%)\end{array}$ \\
\hline Homogeneous & $0 \quad(0)$ & $46(61.3)$ \\
Heterogeneous & $10(100)$ & $20(26.7)$ \\
Negative & $0 \quad(0)$ & $9(12.0)$ \\
Total & $10(100)$ & $75(100.0)$ \\
\hline
\end{tabular}

$\mathrm{P}=0.031$.

specimens. Ten human normal oral mucosa samples and 75 human OSCC lesions (50 primary OSCC and 25 metastatic OSCC samples) were included. In the human normal oral mucosa, a faint but consistent staining was observed, mainly in the plasma membrane in oral mucosa epithelial cells. Stromal cells such as fibroblasts and fibrocytes were not stained by the anti- $\beta 2-\mathrm{M} \mathrm{Ab}$ (Fig. 2A). Most of the OSCC $(88 \%)$ tissue sections showed distinct homogeneous
(Fig. 2B) or heterogeneous staining (Fig. 2C), mainly in the cytoplasm and cytoplasmic membrane of tumor epithelial cells. However, in a few primary OSCC tissues, no staining or staining with weak intensity for $\beta 2-\mathrm{M}$ was noted in the cytoplasm and cytoplasmic membrane of tumor epithelial cells (Fig. 2D). Compared with normal oral mucosa specimens, the frequency of $\beta 2-\mathrm{M}$ expression was significantly increased in OSCC $(\mathrm{P}=0.031)$ (Table III).

Association of $\beta 2-M$ expression with various clinicopathological features in primary OSCC tissues. Of the 50 primary OSCC samples, $26(52 \%)$ exhibited a homogeneous distribution of $\beta 2-\mathrm{M}$ staining, and 15 (30\%) exhibited a heterogeneous distribution within the OSCC cells, while $9(18 \%)$ were negative for $\beta 2-\mathrm{M}$ staining (Table IV). Of the 23 patients classified as T1, T2 in 50 primary OSCC cases, 9 $(39.1 \%)$ showed heterogenous staining and 8 (34.8\%) showed negative staining, while only $6(26.1 \%)$ exhibited homogeneous staining. In contrast, of the 27 patients classified as T3, T4, 20 (74.1\%) presented with homogeneous staining, whereas only $6(22.2 \%)$ showed heterogenous staining and $1(3.7 \%)$ showed negative staining. Compared with primary OSCC of T1, T2 stage, the intensity of $\beta 2-\mathrm{M}$ expression was significantly increased in the primary OSCC specimens of $\mathrm{T} 3$, T4. Up-regulation of $\beta 2-\mathrm{M}$ expression was also associated with lymph node invasion of OSCC. $\beta 2-\mathrm{M}$ expression 


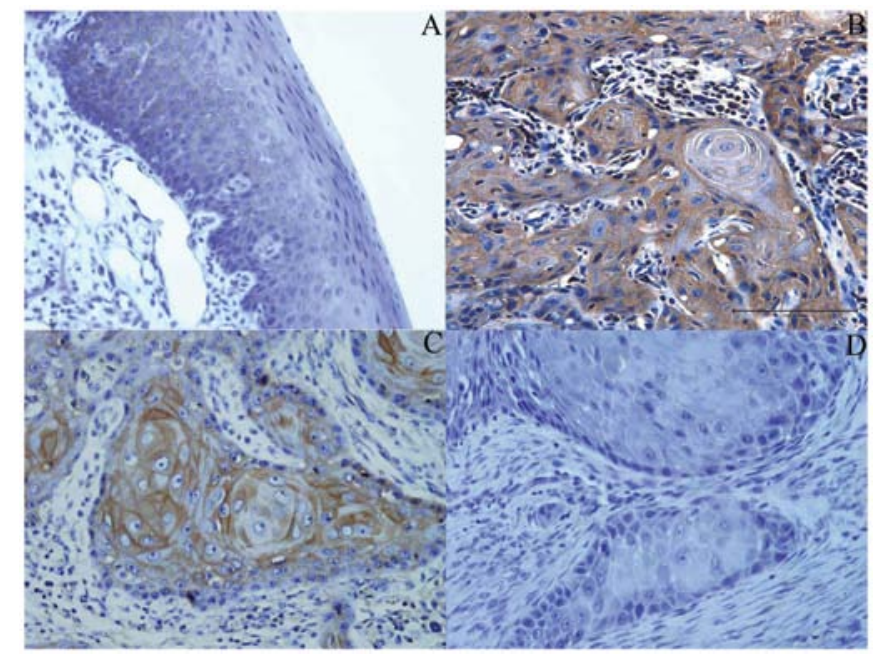

Figure 2. (A) Immunohistochemical staining of $\beta 2-\mathrm{M}$ in normal oral mucosa tissue and (B-D) OSCC tissue. (A) Faint plasma membrane staining was observed in normal oral mucosa epithelial cells. Stromal cells such as fibroblasts and fibrocytes were not stained. $\beta 2-\mathrm{M}$ staining was classified according to three scales in OSCC: (B) homogeneously positive, (C) heterogeneously positive and (D) negative. (A-D, magnification $\mathrm{x} 400)$.

was significantly increased in N-positive patients compared to $\mathrm{N}$-negative patients ( 82.8 vs. $9.5 \%, \mathrm{P}=0.000)$. Regarding clinical stage, in highly malignant stages (III, IV) $67.6 \%$ of samples showed homogeneous staining whereas in low malignant stages (I, II), only $1 \%$ of samples showed homogeneous staining. These data suggest that the staining scores for $\beta 2-\mathrm{M}$ were significantly associated with large tumor size (T3, T4 vs. T1, T2, $\mathrm{P}=0.001$ ), positive nodal status ( $\mathrm{N}$-positive vs. $\mathrm{N}$-negative, $\mathrm{P}=0.000$ ), and advanced clinic stage (III, IV vs. I, II, $\mathrm{P}=0.000$ ) (Table IV). In contrast, there were no correlations between $\beta 2-\mathrm{M}$ expression and gender, age, smoking and alcohol consumption, and pathologic grade.

Up-regulation of $\beta 2-M$ expression in OSCC tissues correlates with tumor metastasis. Intensity of $\beta 2-\mathrm{M}$ staining in OSCC metastatic lesions was significantly stronger than that in the primary OSCC lesions (Fig. 3). Ninenty-two percent of metastatic lesions exhibited a homogeneous distribution of $\beta 2-\mathrm{M}$ expression while $52 \%$ of primary OSCC lesions exhibited homogeneous staining for $\beta 2-\mathrm{M}(\mathrm{P}=0.027)$ (Table $\mathrm{V})$.

\section{Discussion}

In the present study, $\beta 2-\mathrm{M}$ expression in OSCC lesions was evaluated and correlated with tumor progression and metastasis in OSCC patients. The results showed that $\beta 2-\mathrm{M}$ expression was up-regulated in OSCC cell lines and OSCC lesions, and was associated with OSCC progression, invasion and metastasis. Consistent with our results, it was previously found that the suppression of $\beta 2-\mathrm{M}$ expression using small interfering RNA (siRNA) was sufficient to decrease cell migration and invasion in vitro (4). The results of our and other research studies (4), indicate that OSCC lesions should be included in the spectrum of tumors with increased levels of $\beta 2-\mathrm{M}$ expression.

Recent studies have used a wide range of experimental approaches to assess the mitogenic role of $\beta 2-\mathrm{M}$ in malignan-

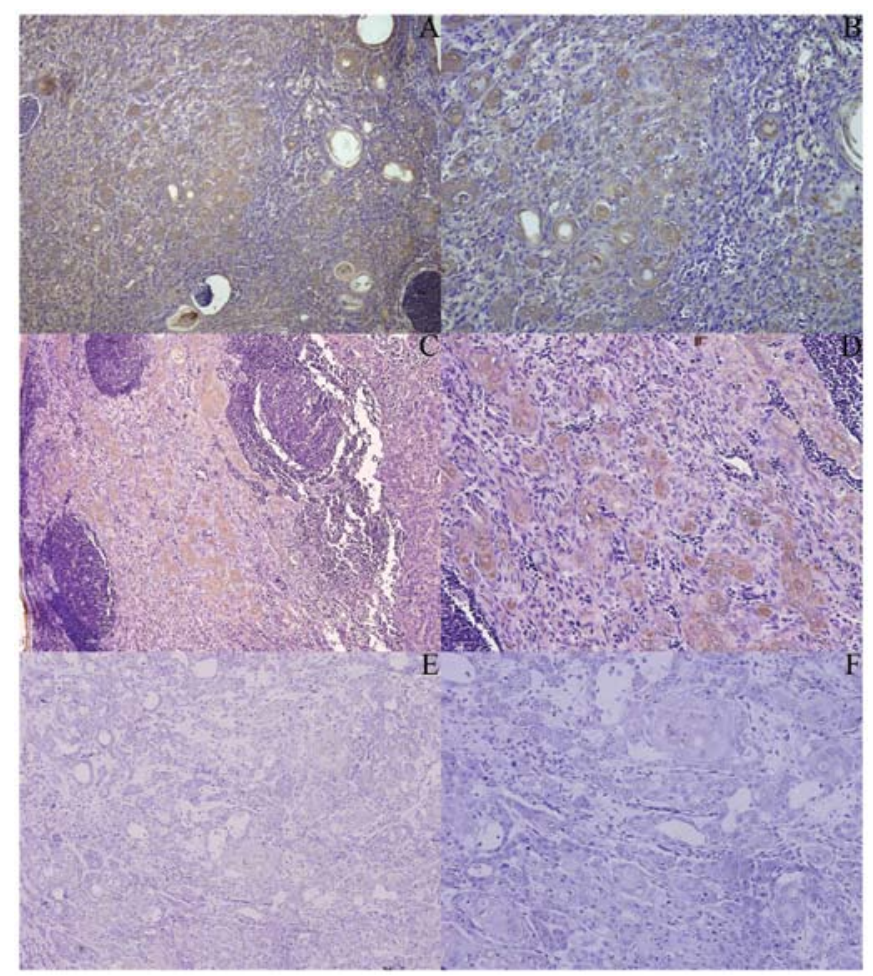

Figure 3. $\beta 2-\mathrm{M}$ immunohistochemistry of metastatic oral squamous cell carcinoma tissues. (A and B) Homogeneously positive; (C and D) heterogeneously positive. (E and F) Negative controls performed by substitution of the primary antibody with mouse non-immune IgG. (A, C, E: magnification x100; B, D, F: magnification $\mathrm{x} 200$ ).

cies. (17-19). These studies have provided strong evidence to show that $\beta 2-\mathrm{M}$ acts similarly to a prototypical oncogenic factor capable of stimulating growth and progression of various types of cancers, including breast cancer (17), prostate cancer (18), lung cancer (19), gastrointestinal (20), nasopharyngeal cancers (21), multiple myeloma (22), and particularly, lymphocytic malignancies (23), such as non-Hodgkin's lymphoma and multiple myeloma. Similar studies have also reported that $\beta 2-\mathrm{M}$ is a growth-promoting factor contributing to the growth and progression of renal cell carcinoma $(24,25)$.

However, previous studies have shown that $\beta 2-\mathrm{M} / \mathrm{MHC}$ class I can serve as important signal-transducing molecules in regulating tumor immunity and progression (26). Increased susceptibility to tumor formation was noted in $\beta 2-\mathrm{M}$ geneknockout mice, which suggests potential regulation of cancer growth by $\beta 2-\mathrm{M}$ (26). Loss of $\beta 2-\mathrm{M}$ expression is clinically important as it has been described in various patient-derived tumor cells, such as in melanomas (27) and cervical carcinoma (28). The possible explanation is that $\beta 2-\mathrm{M}$ is expressed at a constant level on the cell surface. When expression of the $\beta 2-\mathrm{M}$ molecule is below a normal level, defects in the $\beta 2-\mathrm{M} /$ MHC class I signaling pathway may result in tumor immune escape. When expression of the $\beta 2-\mathrm{M}$ molecule is higher than normal, $\beta 2-\mathrm{M}$ promotes tumorigenesis and metastasis as an oncogene.

In some cancers, immunohistochemical evidence suggests that absence of functional ( $\beta 2-\mathrm{M}$-associated) HLA class I molecules may be due to a mutational loss of $\beta 2-\mathrm{M}$ (29); and in other cancers, a decreased level or the loss of $\beta 2-\mathrm{M}$ in tumor 
Table IV. Association of $\beta 2$-microglobulin antigen expression with clinicopathological characteristics in primary OSCC lesions.

\begin{tabular}{|c|c|c|c|c|c|}
\hline & \multirow[b]{2}{*}{$\mathrm{N}$} & \multicolumn{3}{|c|}{$\beta 2$-microglobulin staining pattern } & \multirow[b]{2}{*}{ P-value } \\
\hline & & $\begin{array}{l}\text { Homogeneous } \\
\mathrm{n}(\%)\end{array}$ & $\begin{array}{c}\text { Heterogeneous } \\
\mathrm{n}(\%)\end{array}$ & $\begin{array}{l}\text { Negative } \\
\mathrm{n}(\%)\end{array}$ & \\
\hline \multicolumn{6}{|l|}{ Gender } \\
\hline Female & 19 & $10(52.6)$ & $4(21.1)$ & $5(26.3)$ & 0.368 \\
\hline Male & 31 & $16(51.6)$ & $11(35.5)$ & 4 (12.9) & \\
\hline \multicolumn{6}{|l|}{ Age (years) } \\
\hline$\leq 61$ & 29 & $14(48.3)$ & $9(31.0)$ & $6(20.7)$ & 0.748 \\
\hline$>61$ & 21 & $12(57.1)$ & $6(28.6)$ & $3(14.3)$ & \\
\hline \multicolumn{6}{|l|}{$\begin{array}{l}\text { Smoking and alcohol } \\
\text { consumption }\end{array}$} \\
\hline No & 28 & $16(57.1)$ & $7(25.0)$ & $5(17.9)$ & 0.652 \\
\hline Yes & 22 & $10(45.5)$ & $8(36.4)$ & $4(18.2)$ & \\
\hline \multicolumn{6}{|l|}{ Tumor size } \\
\hline$\leq 4 \mathrm{~cm}(\mathrm{~T} 1+\mathrm{T} 2)$ & 23 & $6(26.1)$ & $9(39.1)$ & $8(34.8)$ & 0.001 \\
\hline$>4$ cm $(\mathrm{T} 3+\mathrm{T} 4)$ & 27 & $20(74.1)$ & $6(22.2)$ & $1(3.7)$ & \\
\hline \multicolumn{6}{|l|}{ Lymph nodes } \\
\hline Negative (0) & 21 & $2(9.5)$ & $10(47.6)$ & $9(42.9)$ & 0.000 \\
\hline Positive (1-2) & 29 & $24(82.8)$ & $5(17.2)$ & $0 \quad(0.0)$ & \\
\hline \multicolumn{6}{|l|}{ Clinical stage } \\
\hline Early (I, II) & 13 & $1 \quad(7.7)$ & $4(30.8)$ & $8(61.5)$ & 0.000 \\
\hline Advanced (III, IV) & 37 & $25(67.6)$ & $11(29.7)$ & 1 (2.7) & \\
\hline \multicolumn{6}{|l|}{ Pathological grade } \\
\hline G1 & 11 & $5(45.5)$ & $4(36.4)$ & $2(18.2)$ & \\
\hline $\mathrm{G} 2$ & 33 & $19(57.6)$ & $7(21.2)$ & $7(21.2)$ & 0.237 \\
\hline G3 & 3 & $2(33.3)$ & $4(66.7)$ & $0 \quad(0.0)$ & \\
\hline
\end{tabular}

The percentage of immunoreactive cells in the entire lesion was evaluated microscopically and scored according to the method described by Kageshita et al (16): homogeneous, $>75 \%$ cells stained in the entire lesion; heterogeneous, $25-75 \%$ cells stained; negative, $<25 \%$ cells stained.

Table V. Profile of $\beta 2$-microglobulin antigen expression in primary oral squamous cell carcinoma and metastases.

\begin{tabular}{|c|c|c|}
\hline & Primary OSCC & Metastases \\
\hline Staining pattern & n $(\%)$ & $\mathrm{n}(\%)$ \\
\hline Homogeneous & $26 \quad(52)$ & $20 \quad(80)$ \\
\hline Heterogeneous & $15 \quad(30)$ & $5(20)$ \\
\hline Negative & 9 (18) & $0 \quad(0)$ \\
\hline Total & $50(100)$ & $25(100)$ \\
\hline
\end{tabular}

$\mathrm{P}=0.027$

cells was found due to the loss of the $\beta 2-\mathrm{M}$ locus, or promoter methylation $(30,31)$. Under these conditions, loss of $\beta 2-\mathrm{M}$ prevents the synthesis of wild-type $\beta 2-\mathrm{M}$ protein, which may lead to alterations in MHC class I surface expression. In our study, was not observed loss of $\beta 2-\mathrm{M}$ in the OSCC lesions. In contrast, levels of $\beta 2-\mathrm{M}$ expression were up-regulated in progressive OSCC lesions. The balance of $\beta 2-\mathrm{M}$ expression at the cell surface was disturbal, which contributed to human cancer growth. Therefore, $\beta 2-\mathrm{M}$ has a wider function than just a housekeeping gene or the role on stabilization and presentation of MHC class I molecular in cells.

Recently, marked antitumor activity has been observed by down-regulation of $\beta 2-\mathrm{M}$ levels using either sequence-specific siRNA or antibodies in cases of both solid tumors and blood malignancies (13). In prostate cancer and renal cancer, growth inhibition of tumors was observed when patients were treated with anti- $\beta 2-\mathrm{M}$ polyclonal or monoclonal antibodies (32), and in myeloma and other hematological malignancies, tumor cell apopotosis was observed using monoclonal $\beta 2-\mathrm{M} \mathrm{Ab}$ and sequence-specific siRNA to $\beta 2-\mathrm{M}$ (33). Thus, $\beta 2-\mathrm{M}$, as an oncogenic factor in various cancer types, appears to be an excellent new target for interrupting human cancer growth. In our study, the association of $\beta 2-\mathrm{M}$ expression with progression and metastasis of OSCC lesions was statistically significant. Whether we can inhibit OSCC progression, invasion or migration by using a similar anti- $\beta 2-\mathrm{M}$ polyclonal or monoclonal antibody needs further study. 


\section{Acknowledgements}

This study was supported by grants from the Doctoral Innovation Foundations of Shanghai Jiao Tong University School (no. BXJ 0922) and National Nature Science Foundation of China (no. 30630065 and 30973344).

\section{References}

1. Imai T, Toyota M, Suzuki $\mathrm{H}$, et al: Epigenetic inactivation of RASSF2 in oral squamous cell carcinoma. Cancer Sci 99: 958-966, 2008.

2. Scully C and Bagan JV: Recent advances in Oral Oncology 2007: imaging, treatment and treatment outcomes. Oral Onco 44: 211-215, 2008

3. Cai ZG, Shi XJ, Gao Y, Wei MJ, Wang CY and Yu GY: Betacatenin expression pattern in primary oral squamous cell carcinoma. Chin Med J (Engl) 121: 1866-1870, 2008.

4. Chen $\mathrm{CH}$, Su CY, Chien CY, et al: Overexpression of beta2-microglobulin is associated with poor survival in patients with oral cavity squamous cell carcinoma and contributes to oral cancer cell migration and invasion. Br J Cancer 99: 1453-1461, 2008.

5. Shi C,Zhu Y,Su Y, Chung LW and Cheng T: Beta2-microglobulin: emerging as a promising cancer therapeutic target. Drug Discov Today 14: 25-30, 2009.

6. Winchester JF, Salsberg JA and Levin NW: Beta-2 microglobulin in ESRD: an in-depth review. Adv Ren Replace Ther 10: 279-309, 2003.

7. Margalit A, Sheikhet HM, Carmi Y, et al: Induction of antitumor immunity by CTL epitopes genetically linked to membraneanchored beta2-microglobulin. J Immunol 176: 217-224, 2006.

8. Christianson GJ, Brooks W, Vekasi S, et al: Beta 2-microglobulin-deficient mice are protected from hypergammaglobulinemia and have defective antibody responses because of increased IgG catabolism. J Immunol 159: 4781-4792, 1997.

9. Hoglund P, Glas R, Menard C, et al: Beta2-microglobulin-deficient NK cells show increased sensitivity to MHC class I-mediated inhibition, but self tolerance does not depend upon target cell expression of $\mathrm{H}-2 \mathrm{~Kb}$ and $\mathrm{Db}$ heavy chains. Eur J Immunol 28 : 370-378, 1998

10. Huang WC, Wu D, Xie Z, et al: Beta2-microglobulin is a signaling and growth-promoting factor for human prostate cancer bone metastasis. Cancer Res 66: 9108-9116, 2006.

11. Nomura T, Huang WC, Zhau HE, et al: Beta2-microglobulin promotes the growth of human renal cell carcinoma through the activation of the protein kinase A, cyclic AMP-responsive element-binding protein, and vascular endothelial growth factor axis. Clin Cancer Res 12: 7294-7305, 2006.

12. Tsimberidou AM, Kantarjian HM, Wen S, et al: The prognostic significance of serum beta2 microglobulin levels in acute myeloid leukemia and prognostic scores predicting survival: analysis of 1,180 patients. Clin Cancer Res 14: 721-730, 2008.

13. Huang WC, Havel JJ, Zhau HE, et al: Beta2-microglobulin signaling blockade inhibited androgen receptor axis and caused apoptosis in human prostate cancer cells. Clin Cancer Res 14: 5341-5347, 2008.

14. Sdek P, Zhang ZY, Cao J, Pan HY, Chen WT and Zheng JW: Alteration of cell-cycle regulatory proteins in human oral epithelial cells immortalized by HPV16 E6 and E7. Int J Oral Maxillofac Surg 35: 653-657, 2006.

15. Zhang L, Yang X, Zhong LP, et al: Decreased expression of Annexin A1 correlates with pathologic differentiation grade in oral squamous cell carcinoma. J Oral Pathol Med 38: 362-370, 2009.

16. Kageshita T, Hirai S, Ono T, Hicklin DJ and Ferrone S: Downregulation of HLA class I antigen-processing molecules in malignant melanoma: association with disease progression. Am J Pathol 154: 745-754, 1999.
17. Klein B, Levin I, Kfir B, Mishaeli M, Shapira J and Klein T: The significance of soluble interleukin-2, soluble interleukin-2 receptors, soluble ICAM-1 and beta 2-microglobulin in breast cancer patients. Tumour Biol 16: 290-296, 1995.

18. Freeman MR: Beta2 microglobulin: a surprising therapeutic target for prostate cancer and renal cell carcinoma. J Urol 178: 10-11, 2007.

19. Nissen MH, Bjerrum OJ, Plesner T, Wilken $M$ and Rorth $\mathrm{M}$ : Modification of beta-2-microglobulin in sera from patients with small cell lung cancer: evidence for involvement of a serine protease. Clin Exp Immunol 67: 425-432, 1987.

20. Kaplan B, Martin BM, Livoff A, Yeremenko D, Livneh A and Cohen HIL: Gastrointestinal beta2microglobulin amyloidosis in hemodialysis patients: biochemical analysis of amyloid proteins in small formalin-fixed paraffin-embedded tissue specimens. Mod Pathol 18: 1610-1617, 2005

21. Lee JK, Tsai SC, Hsieh JF, Ho YJ, Sun SS and Kao CH: Beta-2microglobulin (beta $2 \mathrm{M}$ ) as a tumor marker in nasopharyngeal carcinoma. Anticancer Res 20: 4765-4768, 2000.

22. Kim JE, Yoo C, Lee DH, Kim SW, Lee JS and Suh C: Serum albumin level is a significant prognostic factor reflecting disease severity in symptomatic multiple myeloma. Ann Hematol 89: 391-397, 2009.

23. Delgado J, Pratt G, Phillips N, et al: Beta2-microglobulin is a better predictor of treatment-free survival in patients with chronic lymphocytic leukaemia if adjusted according to glomerular filtration rate. Br J Haematol 145: 801-805, 2009.

24. Federico M, Guglielmi C, Luminari S, et al: Prognostic relevance of serum beta 2 microglobulin in patients with follicular lymphoma treated with anthracycline-containing regimens. A GISL study. Haematologica 92: 1482-1488, 2007.

25. Albitar M, Vose JM, Johnson MM, et al: Clinical relevance of soluble HLA-I and beta2-microglobulin levels in non-Hodgkin's lymphoma and Hodgkin's disease. Leuk Res 31: 139-145, 2007.

26. Sousa AO, Mazzaccaro RJ, Russell RG, et al: Relative contributions of distinct MHC class I-dependent cell populations in protection to tuberculosis infection in mice. Proc Natl Acad Sci USA 97: 4204-4208, 2007.

27. Hicklin DJ, Wang Z, Arienti F, Rivoltini L, Parmiani G and Ferrone S: Beta2-Microglobulin mutations, HLA class I antigen loss, and tumor progression in melanoma. J Clin Invest 101: 2720-2729, 1998.

28. Mehta AM, Jordanova ES, Kenter GG, Ferrone S and Fleuren GJ: Association of antigen processing machinery and HLA class I defects with clinicopathological outcome in cervical carcinoma. Cancer Immunol Immunother 57: 197-206, 2008.

29. del Campo AB, Aptsiauri N, Mendez R, et al: Efficient recovery of HLA class I expression in human tumor cells after beta2microglobulin gene transfer using adenoviral vector: implications for cancer immunotherapy. Scand J Immunol 70: 125-135, 2009.

30. Koene GJ, Arts-Hilkes YH, van der Ven KJ, et al: High level of chromosome 15 aneuploidy in head and neck squamous cell carcinoma lesions identified by FISH analysis: limited value of beta2-microglobulin LOH analysis. Tissue Antigens 64: 452-461, 2004.

31. Feenstra M, Veltkamp M, van Kuik J, et al: HLA class I expression and chromosomal deletions at $6 \mathrm{p}$ and $15 \mathrm{q}$ in head and neck squamous cell carcinomas. Tissue Antigens 54: 235-245, 1999.

32. Yang J, Qian J, Wezeman M, et al: Targeting beta2-microglobulin for induction of tumor apoptosis in human hematological malignancies. Cancer Cell 10: 295-307, 2006.

33. Yang J, Zhang X, Wang J, et al: Anti-beta2-microglobulin monoclonal antibodies induce apoptosis in myeloma cells by recruiting MHC class I to and excluding growth and survival cytokine receptors from lipid rafts. Blood 110: 3028-3035, 2007. 